\title{
9. The evolution and forms of education privatisation within francophone countries
}

\section{Marie-France Lange}

\section{INTRODUCTION}

This chapter provides a brief overview of the current educational landscape in Haiti and most of the francophone (French-speaking) countries in sub-Saharan Africa, with the purpose of highlighting how their social, political and economic contexts relate to the right to education and the growth of private education. Specifically, it examines countries mainly using the French language as the primary means of instruction in primary and secondary education, including 17 countries in French-speaking sub-Saharan Africa ${ }^{1}$ and Haiti, for a total of 18 countries. As the chapter focuses primarily on national systems, it does not include a simultaneous full analysis of international donor relationships with these countries. Instead, it focuses on trends in the growth of private actors and the various forms of private education most prevalent in primary and secondary education, as well as those factors that stimulate this growth of private actors.

The linguistic aspect is important in research on the growth of private education, since the language choice of private schools can sometimes help promote their growth. For example, some private institutions in

1 Countries included are Benin, Burkina Faso, Burundi, Cameroon, Central African Republic, Chad, Côte d'Ivoire, the Democratic Republic of Congo (DRC - Congo Kinshasa), Gabon, Guinea, Madagascar, Mali, Niger, the Republic of Congo (Congo - Brazzaville), Senegal, the Union of Comoros and Togo. We did not select former French-speaking Rwanda, as schools now teach in English having adopted English-language curriculum and programmes since the 2008 education reform. 
French-speaking sub-Saharan Africa have become popular because they do not teach in African languages, whereas countries might require indigenous language instruction in public schools. Similarly, private Arab-Islamic schools, numerous in some countries, including those of the Sahel, favour Arabic. Even if some countries analysed in this chapter have a close common colonial history, they can have significant disparities in their use of French, often used as the language of instruction, administration, and for the media, but rarely as the lingua franca. Instead, African languages usually play this role. In all cases, French is never the mother tongue of the populations of francophone countries of the Global South.

\subsection{Issues and Methodology}

Educational research is under-developed in francophone countries in sub-Saharan Africa, as noted by Nathalie Bonini and Marie-France Lange (2016) in their summary report analysing 40 years of educational research in anthropology, sociology and comparative education in Africa. ${ }^{2}$ It is even less developed in Haiti, for which very few endogenous academic texts exist. Thus, the sharp increase in the presence and roles of commercial actors has so far received relatively little attention by researchers. More recent research ${ }^{3}$ has focused on Arab-Islamic education (Brenner \& Sanankoua, 1991; Gandolfi, 2003; Charlier, 2004; Sy, 2012; Hugon, 2016; Dia et al., 2016), while other research has concentrated more specifically on Catholic education (Compaoré, 2003; Lanoue, 2002, 2003a, 2004). Only rare cases analyse the question concerning the growth of private education institutions (Compaoré \& Pilon, 2017).

This analysis includes both diachronic (How can this change be quantified, and what are the reasons behind its rapid growth?) and synchronic questions (What form does this privatisation take, and what are the consequences in terms of reducing, reproducing, or accentuating educational inequalities and/or in terms of the right to education?). However, data for

2 This study only includes publications of articles and scientific works in English and French (and not those in Spanish and Portuguese) released over the last 40 years. It highlights the low representation of African studies on education, in particular French-speaking research, and the over-representation of some English-speaking African countries in scientific literature.

For an overview of educational research topics developed in Frenchand English-speaking Africa, see Lange, 2003a and Bonini \& Lange, 2016. 
the included countries is scarce and not reliable. Haiti, for example, did not carry out a school census or produce directories between 2002-2003 and 2010-2011. Other States that do not recognise private schools do not include them in the national school statistics. Therefore, this chapter also takes research into account that does not directly relate to the organisation and development of the private sector, including additional scientific literature, some information from the French press, and analysis of school-level statistical data from different countries. To understand public education policies and their positioning vis-à-vis the privatisation of education, we also examined educational strategy documents and national education plans.

\section{THE EDUCATIONAL LANDSCAPE OF FRANCOPHONE COUNTRIES (SUB-SAHARAN AFRICA AND HAITI)}

\subsection{Francophone Education Systems in Sub-Saharan Africa}

While these countries all have different post-independence trajectories, their education systems have, for the most part, retained the structure inherited from colonial systems. Pre-school education is poorly developed, and is, for the most part, found in the private sector. It is mainly available for the advantaged urban social classes, even if some rural community cases have emerged. The primary education cycle is usually made up of six classes, or years, (sometimes five) and ends with the primary school leaving certificate exam. Secondary education, divided into two cycles, is made up of six or seven classes and ends with a final exam, often still called the "baccalauréat", as in France, Benin, Côte d'Ivoire, Senegal and Togo, or known as the "State Examination" in the DRC or the "State Diploma" in Burundi. This exam allows access to higher education with equivalence in all French-speaking countries in sub-Saharan Africa and former metropolitan countries (Belgium and France).

\subsection{The Education System in Haiti}

The Haitian education system is divided into four levels. Pre-school education (not compulsory) comprises three years as in France. Basic education spans nine years and has three cycles with three classes in 
each. ${ }^{4}$ The first two cycles form the "primary school" education (compulsory and free, according to the Haitian constitution, laws of 19 October 1901 and 3 September 1912). The third and fourth levels complete the secondary education (four years of study) and higher education. As a fragile State facing many challenges (discussed below), more than 80 per cent of primary school students are educated in the private sector (MENFP, 2011).

\subsection{Social, Economic and Political Contexts}

As a reminder, the United Nations (UN) classifies most francophone countries in this study as among the world's Least Developed Countries (LDCs) (14 out of 18). ${ }^{5}$ Nevertheless, a broad spectrum of economic and political contexts partially explains the diverse development of education systems in francophone countries and the growth of the private sector in particular. Three types of political contexts emerge: politically stable countries or those emerging from crisis; countries in conflict or in a so-called "fragile" State; and Haiti's own unique situation, a country that could be classified in the second category, but whose particular political history suggests separate study.

\subsubsection{Countries with economic growth and political stability or emerging from crisis}

This classification includes countries such as Senegal, with a stable political regime since its independence, and Côte d'Ivoire, still emerging from crisis (Triplet, 2015) following two civil wars (2002-2007 and 2010-2011). The Senegalese education system has had a stable economic and political context without major crisis since independence. Other countries, such as Benin and Mali, experienced revolts in the early 1990s, which led to National Conferences and made it possible to establish a multiparty system and free elections. In Mali, at the beginning of the 1990s, political democratisation triggered a strong social demand for 
education, diversification of the educational field, and the rapid growth of the provision of education and, in particular, private education (Lange \& Diarra, 1999). Burkina Faso experienced a period without civil war between October 1987 (the date of Blaise Compaoré's coup d'état) and November 2014 (the date when he was overthrown). The fall of this authoritarian regime occurred much later than in Mali or Benin and, although a more democratic political system emerged, the country has not yet stabilised.

Gabon, currently the richest francophone country in Africa, is a special case which has experienced continuous development in both its economy and its education system but lacks political democratisation. Paradoxically, even with improving educational indicators such as high enrolment rates, the actual system management appears to mirror that of a country at war such as the Central African Republic, rather than a relatively rich and peaceful country. Indeed, Gabon has not produced school statistics for several years, does not produce a ten-year education plan or any education policies, and relies on support from international organisations to carry out the basic management operations of its education system. ${ }^{6}$ The case of Gabon shows that economic wealth and political stability (due to an authoritarian regime) do not ensure effective education system management.

Furthermore, even relatively politically stable countries, as mentioned above, have experienced periods of crisis in their education systems, which have led to long strikes, either of pupils and students, or of teachers, or both. Most French-speaking African countries have lost one or several years (une année blanche, in French) in the past three decades. ${ }^{7}$ This has contributed to the rapid development of private schools (in which teachers do not strike) in many cases (Gabon, Mali, Senegal, etc.), a phenomenon also observed in countries in conflict situations or in so-called "fragile" States.

6 UNESCO, UNESCO Office, Libreville, 2017, http://www.unesco.org/ new/fr/bureau-de-lunesco-a-libreville/about-this-office/single-view/news/unesco _encourages_gabon_to_draw_up_a_sectoral_plan_for_educa/.

7 An "année blanche" or a "lost year" is defined in francophone Africa as an invalidated school year that all students must repeat due to strikes. Such years do not count as repetition in student academic records, but as an "année blanche". However, States have validated certain strike years, despite only a few lessons actually occurring, by changing the school calendar (Lange, 1998: 243; Lange et al., 2006). 


\subsubsection{Countries in conflict or so-called "fragile" States}

A large number of African countries have recently faced or still have situations of war or conflict. As an example, the population of sub-Saharan Africa represented approximately 14 per cent of the world's population in 2019; however, the proportion of African refugees or displaced people assisted by the United Nations High Commission for Refugees (UNHCR) stood at more than 26 per cent. The consequences of this violence on the development of education systems, their organisation, and the growth of private, for-profit or non-profit, schools is significant. The Comoros, for example, have an unstable political situation and an undemocratic political regime and have also experienced numerous teachers' strikes, prompting some parents to turn to private education (Lacoste \& Leignel, 2016).

Education in conflict situations in francophone Africa has benefited from recent research that helps understand the effects of wars on the functioning of education systems (Guth, 2003; Lanoue, 2003b; Azoh et al., 2009; Triplet, 2015; Murseli, 2019). These studies focus on the consequences of wars and on the adaptation of education systems and families in the face of often failing States. Some describe the emergence of new types of schools (Murseli, 2019) of uncertain status: being neither entirely public nor private, sometimes not State-recognised, and financed by international aid.

In conclusion, the political situation, the State's influence, and its role in the management of the education system are decisive in the development of private education, either because of a public policy of voluntary (instead of mandatory) education, or because of the inability of States to ensure access to quality schooling for as many as possible under safe conditions. When States fail, education systems change considerably, either for reasons of conflict or because the States themselves are corrupt. The role of private education (for-profit or non-profit), its foundations and its organisation is closely dependent on the political systems in place.

\subsubsection{Haiti's unique situation}

Haiti's educational background is unique and linked to the country's history. It was economically fragile from independence in 1804, due to the huge debt (reimbursement of expelled French settlers) that the Haiti had to pay to France. This weak economic status was compounded by military instability (fear of seeing France try to regain the territory, war with Spain, and the occupation of the United States between 1915 and 1934), ongoing political unrest due to social conflicts between mulattoes 
and blacks ${ }^{8}$ and corruption that legitimises the political establishment. Furthermore, natural disasters have added to these unfavourable economic, social and political conditions. More recently, Haiti experienced a succession of hurricanes in 2008, an earthquake in January 2010, followed by a cholera epidemic. Then, in October 2016, Hurricane Matthew particularly affected the department of Grand'Anse, ${ }^{9}$ destroying roads and buildings in its wake and impacting 2.1 million people (UN Office for the Coordination of Humanitarian Affairs, 2016).

Most recently, the political crises in 2019 showed the extent of the economic and political difficulties, which hampered the establishment of a stable democratic system and made it difficult to establish an effective public education system. In fact, despite the Haitian State promoting many laws favouring Education for All (EFA) for centuries, economic and political insecurity have led to insufficient financial and institutional means, with the growth of primary and secondary education still relying, for the most part, on the private sector.

\section{CHARACTERISTICS OF PRIVATE EDUCATION, GROWTH OF THE SECTOR, AND THE ROLE OF THE VARIOUS ACTORS}

\subsection{A Brief History}

At independence, in countries of the Sahel (Burkina Faso, Chad, Mali, Niger, etc.), the primary education enrolment rate was often less than 10 per cent in 1960 and secondary education was almost non-existent. The same is true of some countries in Central Africa such as the Central African Republic. Private education was also highly under-developed, except in two mandated countries, Togo and Cameroon. ${ }^{10}$ This dates

8 With regard to the conflicts between the Blacks and mulattoes, see the article by David Nicholls (1978) https://www.persee.fr/doc/ outre 1631-0438_2003 num_90_340_4045 or Micheline Labelle's publication (1987) https://pdfs.semanticscholar.org/24fc/2614ca8bb4a753c6dccc55d46b 78d44a8e47.pdf.

$9 \quad$ Haiti has ten departments that are divided into arrondissements or districts, and these districts are further divided into communes (42 arrondissements and 145 communes for the whole country).

10 As a reminder, these two countries are former German colonies conquered during the First World War by the French and the English and first placed under the supervision of the League of Nations, and later the UN. Their League 
to the French concept of a centralised education system, as opposed to former Belgian colonies, such as the DRC, where "the definition of education as a public good, governed exclusively under the State, $[\ldots]$ is foreign to the origin of Congolese schools" (André and Poncelet, 2013: 272).

In former French colonies, the separation of Church and State also contributed to the development of public education (Guth, 1990), while in the former Belgian colonies, the Holy See signed agreements (André $\&$ Poncelet, 2013: 276). The presence of Christian and Muslim religions meant that the private sector development varied and led to the coexistence of many different types of private schools (private Christian schools under contract with the State, unrecognised Koranic schools, madrasas, or Franco-Arabic public or private schools, recognised or not). Even today, the roles of private education, its different forms, and its relationship with the State have their origins, in part, in colonial history.

During the first two decades after independence (1960-1980), African States invested highly in both enabling as many children as possible to go to school and training the elites to replace colonial cadres. Policies to nationalise private schools were put in place in Congo (Makonda, 1988), Zaire (André and Poncelet, 2013), Benin, or Guinea (Lange, 2001). Other countries, such as Côte d'Ivoire, integrated private Catholic schools into the public sector (Lanoue, 2003a). Later, in 1969, Burkina Faso gradually nationalised Catholic schools and in 1970 enrolments in the private sector represented only 2.8 per cent of primary school students.

Some governments eventually allowed the development of private education, but in the early 1990 s, the proportion of the private sector involved in primary education was still very low (less than 5 per cent) as in Benin, Burundi, Guinea, Mali and Niger (see Table 9.1). However, as has already been mentioned, school statistics only take into account those private schools recognised by the State. One of the difficulties of measuring the development of the private sector is also due to the fact that any census of private schools has varied widely over the years.

On the one hand, this variation appears when Ministries of Education have sometimes refused to recognise certain schools and therefore not listed them (see the case of "clandestine schools" in Togo and "parent

of Nations and UN status allowed for greater investment in education and a larger number of private schools (Lange, 1998). Ruanda-Urundi (1916-1960) was a Belgian protectorate until the independence of Rwanda and Burundi in 1962 but did not have the same outcomes in terms of education development. 
Table $9.1 \quad$ Proportion of private sector providers in primary education in francophone countries (1990-1992)

\begin{tabular}{lccc}
\hline Country & $\mathbf{1 9 9 0}$ & $\mathbf{1 9 9 1}$ & $\mathbf{1 9 9 2}$ \\
\hline Benin & - & 3.4 & 3.8 \\
Burkina Faso & 9.1 & 8.6 & 8.0 \\
Burundi & 0.9 & 0.8 & 0.7 \\
Cameroon & 27.2 & 25.2 & 24.9 \\
Central African Republic & - & - & - \\
Chad & 5.4 & 6.0 & 5.5 \\
Comoros & - & - & 1.0 \\
Congo & - & - & 0.4 \\
Côte d'Ivoire & 11.3 & 10.4 & 9.6 \\
DRC & - & - & - \\
Gabon & - & - & 31.0 \\
Guinea & 2.9 & 2.4 & 4.6 \\
Haiti & - & - & 67.0 \\
Madagascar & 16.7 & 17.8 & 21.8 \\
Mali & 3.6 & 3.3 & 16.0 \\
Niger & 2.8 & 2.8 & 2.8 \\
Senegal & 8.9 & 9.2 & 9.6 \\
Togo & 23.8 & 24.9 & 24.6 \\
\hline
\end{tabular}

Source: Table compiled from data from the UNESCO Institute for Statistics (UIS.Stat) (http://data.uis.unesco.org/?lang=en).

schools" in Chad). In several African countries such as Mali, Koranic or Arab-Islamic schools did not fall under the authority of the Ministry of Education, but under the Ministry of the Interior (Religious Affairs) and were only integrated into the Ministry of Education at a later date. This could explain the data showing that the number of Arab-Islamic schools was suddenly rapidly expanding, while in fact the statistical increase was due to an improved census database. The same phenomenon occurred with community schools.

\subsection{Recent Trends in the Growth of Private Education}

The background information above illustrates how measuring the growth of the private sector is difficult due to low availability of statistical data and a lack of consistency in terms of its collection. As shown in Table 
Table 9.2 Growth of enrolments in private education, francophone countries in 2000, 2011, and 2017, by level*

\begin{tabular}{|c|c|c|c|c|c|c|c|c|}
\hline \multirow[b]{2}{*}{ Country } & \multicolumn{3}{|c|}{2000} & \multicolumn{2}{|c|}{2011} & \multicolumn{3}{|c|}{2017} \\
\hline & $\mathrm{PE}$ & LSE & USE & LSE & USE & $\mathrm{PE}$ & LSE & USE \\
\hline Benin & 10.1 & 13.5 & 27.4 & 15.9 & 26.5 & 23.2 & - & - \\
\hline Burkina Faso & 11.4 & 33.8 & 36 & 39.6 & 48.6 & 20.1 & 39.2 & 48.6 \\
\hline Burundi & - & - & - & 8.2 & 12.7 & 1.9 & 3 & 14.3 \\
\hline Cameroun & 27.3 & - & - & 23 & 31.6 & - & - & - \\
\hline $\begin{array}{l}\text { Central African } \\
\text { Republic }\end{array}$ & - & - & - & - & - & - & 24.7 & 19.6 \\
\hline Chad & - & 15.2 & 14.2 & 14.4 & 17.1 & - & - & - \\
\hline Comoros & 10.7 & 40.3 & - & 47.2 & - & 18.8 & 46.7 & 63.5 \\
\hline Congo & 15.2 & 15.2 & - & - & - & - & - & - \\
\hline Côte d'Ivoire & 11.6 & - & - & - & - & 13.9 & 47.5 & 59.6 \\
\hline DRC & - & - & - & - & - & - & - & - \\
\hline Gabon & - & - & - & - & - & - & - & - \\
\hline Guinea & 16.1 & 8.2 & - & 23.9 & 31.7 & - & - & - \\
\hline Haiti & - & - & - & - & - & - & - & - \\
\hline Madagascar & 22.6 & - & - & 32.9 & 48.4 & - & 40.1 & 49.2 \\
\hline Mali & - & 13.9 & - & 18.3 & 63.1 & 42.7 & 29.2 & - \\
\hline Niger & 4.3 & - & - & - & - & 3.6 & 12.7 & 24.3 \\
\hline Senegal & 10.6 & 28.8 & 18.9 & - & - & 16.3 & 17.3 & 32.7 \\
\hline Togo & 36.9 & - & - & 21 & 29.4 & 30.2 & 25.8 & 30.7 \\
\hline
\end{tabular}

* PE - primary education; LSE - lower secondary education; USE - upper secondary education

Source: Table compiled from data from the UNESCO Institute for Statistics (UIS.Stat) (http://data.uis.unesco.org/?lang=en).

9.2, while all 18 French-speaking countries were studied, some of them had no data available. Table 9.2 reveals that growth in private primary education varies from country to country. One group of countries (Benin, Burkina Faso, Comoros, Congo, Guinea) experienced a significant increase in the number of enrolments in the private sector, while a second group (Côte d'Ivoire, Niger) saw no growth at all, and a third group saw a slight decrease in numbers (Togo, Cameroon). Countries experiencing the greatest growth in the private sector also had a very low representation of the private sector in 1990 (see Table 9.1). 
For lower secondary education (Table 9.2), growth in the private sector appears relatively stable between 2000 and 2017. Some countries experienced a slight increase in the number of enrolments in private schools such as Burkina Faso, Comoros, and particularly Guinea and Mali, in contrast to Senegal, whose numbers dropped significantly. However, a decrease in private education enrolment does not necessarily mean that the number of students enrolled in the private sector has dropped; it may indicate that the number of students enrolled in the public sector grew more rapidly due to State investments.

Likewise, for upper secondary education, growth in the private sector appeared mixed (Table 9.2). Several countries experienced a rapid increase in enrolments in the private sector, such as Burkina Faso, the Comoros, Côte d'Ivoire, Guinea and Mali. For upper secondary education, significant increases in the enrolment in private education correspond to those countries (Burkina Faso, Mali, Senegal), which gave priority to primary education and invested little in upper secondary schools.

Despite differences between countries, the general trend is towards an increase in enrolments in private education in the upper secondary level. In some countries, the private sector is becoming as or more important than the public sector (Burkina Faso, Comoros, Côte d'Ivoire, Madagascar, Mali), which indicates that States have withdrawn from investing in secondary education and, more specifically, in upper secondary schooling. In Burkina Faso or Mali, following national education policies implemented in Africa since the Jomtien Conference (1990) and the Dakar Forum (2000), governments have received increased international aid (De Grauwe, 2016), which gave priority to comprehensive primary education and hindered investments in secondary education, which is not considered a priority. An increase in the number of pupils in private education does not always mean that schooling falls under the sole responsibility of the parents. Indeed, private education can benefit from State aid or funding. However, private schools tend to settle in areas where the demand for education is good (with the exception of community schools), which increases social inequalities in terms of access to education. 


\subsection{Diversification of the Scope of Education in Francophone Countries}

As previously mentioned, private education was under-developed at the time of independence and some African countries had even nationalised their entire education system. The processes of privatising education mainly began following major international conferences on education, and commitments made to ensure the development of EFA. These processes have led to the emergence of new types of schools alongside public institutions (especially in primary education, at the beginning). The rapid growth of these new types of schools in sub-Saharan Africa is thought to be a process of "diversifying the scope of education" (Lange \& Diarra, 1999; Lange, 2003b), which has enabled an increase in private institutions whether for profit or not. Diversification of the field of education and the process of privatising education have been defined as corresponding:

to a process of State withdrawal, as can be noted by the appearance [of private institutions], or their rapid development alongside public schools (often in the majority, or even exclusive in the early 1990s, depending on the country), of new types of school (secular or religious private schools, local or community schools ...) and the legal recognition of these new schools. (Lange, 2003b: $150)$.

The diversification of education has taken extreme forms in Africa, as seen in Mali, where up to eight types of formal schools and two types of non-formal schools for primary education operate (Lange \& Diarra, 1999: 172). This broad diversity of private schools, their modus operandi, and funding mechanisms have received little research attention in francophone Africa (Kitaev, 1999), although some researchers have addressed the process of privatising education (Kitaev, 1999; Lewandowski, 2007; Wodon, 2014). To overcome the poor quality of information afforded by education statistics in Africa, some authors such as Quentin Wodon (2014) use data from household surveys and do not rely solely on those from the Ministries of Education; however, such data do not provide information on financing methods or the actual organisation of private institutions. Lastly, it should be noted that Haiti's particularity is due to the long-time prominence of private education. Haiti has never known a highly centralised, dominant public education system like most francophone African countries. 
The diversity of the educational scope can be seen from the forms taken by privatisation - from the many different types of schools that are created, transformed, or disappear. Tables showing the wide range of schools only reflect the situation of a country at a particular time. Indeed, these new schools often emerge in an unstable or difficult social, institutional, or financial state, driven by the actions of various actors (international and State, parents of students, local communities, etc.) who approve or oppose choices related to the different types of schools, operating methods and funding.

\subsection{Forms of Educational Privatisation}

An important difference in the forms of privatisation is between private for-profit and private non-profit, which respond to very different social demands. In the first case (private for-profit), schools are created either by religious communities or by small private entrepreneurs. In the second case (private non-profit), community schools are created, financed and managed by the parents. In both cases, schools charge tuition fees and parents are usually responsible for financing their children's schooling.

In francophone Africa, the location of these schools differs greatly according to the urban or rural environment. In urban areas, mainly secular, private, for-profit schools have opened. These differ greatly depending on whether or not they meet a social demand from wealthy parents who wish to move away from public school due to reforms imposed by the State. For example, the imposition of double shifts ${ }^{11}$ in an urban environment encouraged the creation of private schools that committed to offering students single shifts. Additionally, due to numerous upheavals in public education, some parents preferred to turn to private schools less affected by strikes. Indeed, African education systems were shaken by teachers' strikes following the imposition of a change in their status, among other things (previously civil servants, the majority of

11 Double shift (or double session) refers to the schooling of two groups of students by one teacher in the same classroom; one group of students has lessons in the morning, the other in the afternoon. Not only are the class times reduced, but teachers no longer have time to correct as many exercises, since the number of students per teacher is doubled. This double-shift system concerns the majority of French-speaking African countries (Benin, Burkina Faso, Burundi, the Central African Republic, Chad, Côte d'Ivoire, DRC, Guinea, Mali, Niger and Senegal) and it also exists in Haiti. 
teachers in francophone Africa are now contract or community workers). Other reforms, such as the imposition of national African languages in public schools or curriculum changes, have also prompted some parents to "flee" public schools.

In general, the deterioration of learning conditions has favoured the growth of private schools in urban areas, with these schools now intended for the middle or upper social classes. However, the most disadvantaged urban populations also find themselves turning to private schools. This occurs primarily for populations living in disadvantaged, peripheral or informal neighbourhoods of capitals or big cities and who benefit very little from State investments. Whether these schools are recognised by the State or not has little influence over enrolment, because, in certain disadvantaged areas of large African cities, parents have no choice. The provision of education is limited to schools that are not recognised ${ }^{12}$ and offer variable levels education. The same phenomenon is observed with Haiti's "Borlette schools", often described as very low-quality schools, for the poorest families.

The opening of private for-profit schools depends, therefore, on the social demand for education. Some are very expensive for the privileged classes (such as international schools), while others are more affordable and geared towards the middle classes. So-called "low cost schools" are intended for more disadvantaged populations. Other religious schools are created to meet a social demand, which favours religious education (Christian or Muslim). These private schools can have a wide variety of forms, be recognised or not, and can target the poorest children or those of the privileged classes.

In rural Africa, the very low presence of private, for-profit schools ${ }^{13}$ is offset by the presence of community schools (set up by the parents of students), which respond to a lack of State or private education facilities. The phenomenon of schools created by parents is not new; during the time of French colonisation, parents used to set up schools considered as underground or illegal schools. Likewise, Christian missions opened

12 This is the case, for example, in certain districts of Ouagadougou. Every year, at the start of the new school year, the Ministry of Education publishes a list of authorised schools, and some districts only have unofficial schools; even though parents are informed of a school's illegality', they have no other option to enrol their children in school.

13 With the exception of rich rural regions producing coffee and cocoa in Côte d'Ivoire, Cameroon or Togo for example. 
schools that colonial authorities sometimes closed (Lange, 1998). At the end of the 1980s, school authorities started to recognise parent-led schools, due to both strong social demand and the financial incapacity of States subjected to the structural adjustment plans (Grégoire and Lange, 2018) to respond to this social demand for education, as well as the influence of international non-governmental organisations (NGOs) or UN organisations. Moreover, these schools changed their names, as in Togo where "clandestine schools" became "local initiative schools" (EDIL) recognised by the State or in Chad, where "spontaneous schools" became "community schools" (Lange, 1998; Marchand, 2000).

UN organisations may have assisted or supported these schools, such as UNICEF, which helped "village schools" in Mali (Lange \& Diara, 1999), or international NGOs, which helped "clandestine schools" in Togo. International NGOs, alongside UN institutions, used their influence to get such schools recognised. Thereafter, States provide these schools with a legal framework ${ }^{14}$ and a large number of countries now have community schools (Central African Republic, Chad, Haiti, Madagascar, Mali, Niger, Senegal, Togo, etc.). Even if the phenomenon of community schools may be negligible in some countries such as Niger, in others, such as Mali or Chad for example, they account for a significant percentage of primary school children. In Chad, around 20 per cent of primary school pupils are enrolled in community-based education.

Community schools exist predominantly for primary education - very few exist for lower secondary and almost none for upper secondary education. While the presence of community schools is still important today, their numbers are trending downward in many countries. The excessive financial burden borne by parents (who, more often than not, are poor) is encouraging States to transform these schools into public schools. Additionally, due to decentralisation processes implemented in African countries since the 1990s, some community schools became communal schools and were thereafter registered as public schools. Lastly, some entrepreneurs have created community schools, which turned out to be for-profit schools (for example, in Mali, conflicts in the management of community schools in 2016 halted authorisations for these schools). nity schools and Circular no. 1703 MEN/SG 29 December 2016 that imposed the provisional ban on the opening of community schools. 
This educational landscape littered with, in some countries, a large number of very different types of schools (as in Haiti, see Table 9.3), is constantly being reconfigured due to social dynamics and public education policies. Additionally, school classification is not always uniform even within the same country. For this study, the classification of education statistics enables the measurement of the respective share of each type and its growth. However, this classification does not always reveal who is funding education. Some institutions, such as Catholic or private schools, are often funded by the State as in Burkina Faso, Mali or Senegal, whereas parents can sometimes end up paying for teachers in public schools. For example, in Chad, in 2016, 64 per cent of primary school teachers were community teachers. The same is true in the Central African Republic, where approximately half of primary school teachers are community teachers and therefore funded by the parents of students. A school registered as public does not mean that the State will automatically provide premises, furniture, educational material or trained teachers. ${ }^{15}$ Students' parents are sometimes responsible for building public schools, making the furniture and paying teachers.

\subsection{The Role of International Actors and the States}

The role of international actors has been instrumental in the growth of private education in francophone Africa. Funding plans for the education sector for African countries have all been influenced by international agendas. These externally funded education policies are aimed at educating the greatest number of children at the lowest cost. In doing so, the quality of education in public schools ${ }^{16}$ has decreased and promoted a loss of credibility in public schools.

The development of national education policies has thus depended on imposed reforms. For example, the double-shift system was imposed and

15 Education authorities define a school as "public": this is recognised by the State and parents, even if the State has little intervention. Education statistics take into account the school and the number of pupils, but do not include teachers paid by the parents.

16 Various reforms have contributed to lowering the quality of education: double shifts, an increase in the student/teacher ratio, and a drop in the level of teacher training. In French-speaking Africa, during the Structural Adjustment Policies (SAPs), teacher training colleges were closed to save money and teachers were recruited without any or very limited training of only a few weeks or months. This was notably the case in Burkina Faso and Mali. 
Table 9.3 Examples of recognised schools in francophone countries (primary education, formal schools)

\begin{tabular}{cccc}
\hline Gabon & Niger & Central African Republic & Haiti \\
\hline Public & Public & Public & Secular \\
Catholic & Private & Communal & Congregational \\
Protestant & Community & Private Catholic & Communal \\
Christian Alliance & & Private secular & Community \\
Islamic & & Private protestant & Presbyter \\
Accredited & & Franco-Arabic & Episcopal \\
Private secular & & Protestant (mission) \\
& & & Protestant (independent) \\
& & & Other \\
\hline
\end{tabular}

Sources:

1. For Gabon, school year 2013-2014 (Directorate of Primary Education (DEP) and school districts). Approved schools (or écoles publiques conventionnées (EPC) in French) are public schools in Gabon, which adhere to Gabonese regulations and fall under the administrative and pedagogical supervision of the Ministry of Education. These government-run public schools are structured according to an agreement between the Gabonese Republic and the French Republic. Education is based on both French and Gabonese programmes (according to Article 4 of the 2015 Agreement). Students work towards the Gabonese Certificate of Primary Education (https://www.mlfmonde.org/ etablissements/ecole-publique-conventionnee-gros-bouquet-1/).

2. For the Central African Republic, school year 2016-2017 (Central African Republic, MEPSTA, DGESP, 2017). Community schools no longer officially exist in the Central African Republic; however, teachers paid by parents are often considered "community teachers".

3. For Niger, school year 2015-2016 (Republic of Niger, MEP/A/PLN/EC, 2016). The directory identifies 75 community schools in 2012 compared to only seven in 2016 and indicates that: "According to their statute, the majority of these community schools have been turned over to the State, and thus transformed into public schools" (2016:12).

4. For Haiti, 2010-2011 school year (MENFP, 2011). It should be noted that "Borlette schools" are not listed, as they are not officially recognised.

financed by the World Bank. International aid has also funded priorities given to primary education, rural areas, and policies promoting girls' education (Lange, 2003b: 157) and some donor-driven reforms therefore stop when funding is cut. This was the case, for example, of community schools in the Central African Republic, created in 1994 with funding from UNICEF and shut down in 2000 when funding ceased (Murseli, 2018: 97-98).

The actual role of the aid-dependent State is reduced due to loan and grant conditions. The international agenda (Millennium Development Goals (MDGs), then Sustainable Development Goals (SDGs)) also 
sometimes requires parallel planning between national plans and external demands (Grégoire and Lange, 2018). Thus, African countries, who depend on international aid to partially finance their education systems, have moved away from their "educational projects" policy tool to that of the "ten-year education plan", based on programmes organised and funded by donors. All of these plans include proposals for the development of private education.

These countries have thus experienced many original styles of privatising education, including attempts to delegate the management of public schools to private entrepreneurs. Most of the time, however, these experiments have failed, as in Mali, where school promoters received loans from the World Bank for school construction, leading to schools eventually closing or being handed over to the State because they could never repay the debts incurred (Grégoire and Lange, 2018). In Burkina Faso, the practice of leasing educational establishments to private companies or delegating their management to NGOs faced the same issue, namely a difficulty to find enough solvent families to cover the costs.

On the whole, while private, for-profit education has developed in French-speaking sub-Saharan Africa, certain forms of privatisation and commodification have not been able to stay the course. The first obstacle to a more rapid expansion of privatisation seems to be the insolvency of families, especially in rural areas and city outskirts. Furthermore, in urban areas, the wealthiest social classes use international schools, such as French schools and lycées or other international schools opened locally by private entrepreneurs. The advantages of French schools and lycées are manifold: they are partly funded by France, they issue French or dual diplomas, they allow enrolment in French university, and the cost remains affordable because of the co-financing. However, private international companies such as Enko Education ${ }^{17}$ have very recently arrived in several French-speaking African countries, such as in Douala in Cameroon and Abidjan in Côte d'Ivoire (2016), in Dakar in Senegal (2017) and in Burkina Faso and Mali (2018). To operate in these countries, these companies often partner with or purchase local private schools according to the relevant legal requirements (Lange and Henaff,

17 Enko Education was founded by Cyrille Nkontchou from Cameroon (who created the investment fund Enko Capital in Johannesburg in 2007) and Eric Pignot. 
2015). It is still unclear whether this new type of private international school will find its public. ${ }^{18}$

\subsection{The Role of Social Demand}

Regarding the social demand for education, two types of strategies can be identified. The first corresponds to restricted choice, the case for the populations living on the outskirts of large African cities since the time of the SAPs (between 1980 and 1995, depending on the country). This period saw little to no investment in education in the suburbs by the States, mainly due to financial issues related to the SAPs. Thereafter, the Heavily Indebted Poor Country Initiative (HIPC) programmes enabled significant public investment, but only in primary education and primarily for disadvantaged rural areas. As a result, private schools (with the exception of community schools) mainly developed in urban areas (Compaoré \& Pilon, 2017; Assane Igodoe, 2018).

Families in lower-income neighbourhoods are unable to send their children to public schools, as they are more or less non-existent (Burkina Faso, Haiti). This lack of public schools is also observed in certain rural areas and obliges local populations to create their own community schools. Additionally, when States fail (due to political crises or armed conflicts), the populations are also forced to organise themselves to create and manage schools (as in the case of the first "spontaneous school" in Chad). This situation mainly concerns primary education, because parents often do not have the financial resources to ensure the functioning of secondary schools. Due to this lack of public schools, the local populations organise themselves to create these community schools.

The middle and upper classes adopt a different strategy. Choice is driven by a search for higher quality education. These families also choose to avoid public schools as a means to refuse specific reforms, as mentioned above, or simply to avoid public schools altogether, as the quality has deteriorated considerably. In Dakar, for example, "the strengthening of a multi-tiered school system" (Lewandowski, 2011: 44) has occurred due to the poor quality of public schools and therefore their

18 Enko Education schools are intended for the wealthy social classes; the tuition fees are high (approx. US\$4,000 per year), but slightly lower than those of the French schools. Their curriculum leads the International Baccalaureate (French-English bilingual education), which allows students to enrol in Englishor French-speaking universities. 
low success rates in exams. In these cases, the provision of education is not only expanding, but becoming more hierarchical. The avoidance of public schools by the wealthier social classes in cities further reinforces the privatisation of education, as these social classes no longer use their influence to defend the public schools they do not use. Thus, the process of diversification and privatisation of education is accentuated by the educational strategies of families.

\section{CONCLUSION}

From a research perspective, studying the evolution of the privatisation of education in the chosen francophone countries is complicated because of the lack of research and the absence of statistics or the irregularity of their release. The failure to identify a significant portion of new private schools also accentuates the difficulties in capturing the extent of the phenomenon. However, the analysis of the 18 French-speaking countries included in the sample provides some information regarding trends in the growth and specificities of private education. Unlike Haiti, which never really built a public education service, most African countries opted for a unified and centralised public system at the time of independence (especially in the former French colonies). The 1990s then saw this pattern deeply upset both by the financial crises that imposed structural adjustment plans and the democratisation of the political systems of certain African countries following the National Conferences (Robinson, 1994), which allowed the expression of the social demand for education. ${ }^{19}$ These two phenomena led to the creation of private, for-profit and non-profit schools.

As already mentioned, the privatisation of education is first observed in the cities, where populations have the financial means to pay school fees, but also occurs in rural areas through private, non-profit schools (community schools). The main challenges to the growth of private education arise in terms of the right to education and the reproduction of educational inequalities. The right to education is called into question

19 The social demand for education concerns both individual, family and collective education strategies within a given social space (Lange, 2003b; Lange et al., 2006), which means that social actors carry out their educational choices and adjust their strategies according to the positions of other actors in the educational field, and also other fields (political, economic, cultural) (Lange and Yaro, 2003). 
by the absence of public schools, accessible to all, both from a physical and financial point of view, or by the excessive cost of private schools. In terms of consequences on educational inequalities these are related to inequalities of access, the transmission of knowledge and, ultimately, academic success.

The privatisation of education has a significant influence on an individual's educational path and is determined by the quality of education according to the type of school: school hierarchy increases due to the fact that the provision of private education is based on family financial solvency. Private schools thus target different audiences: the very privileged social classes benefit from quality private international or national institutions, the middle classes attend less successful schools with more affordable prices, and the most disadvantaged social classes only have access to schools that do not enable knowledge transfer or the passing of exams. The privatisation of education can also increase gender inequalities in terms of schooling, with parents making choices in favour of boys if school fees are too high.

The rapid growth of the private sector has been accompanied by a lack of awareness of the phenomenon. States are often unable to identify all private schools. Furthermore, ex post control remains inadequate. Governments have not monitored this rapid growth of private education well and the means of regulation are either non-existent or ineffective. While many African countries publish a list of authorised private schools at the start of each new school year (Burkina Faso, Senegal, etc.), in capitals such as Ouagadougou or Dakar, parents have no other choice than to send their children to unrecognised private schools due to a lack of recognised schools. The subject of education privatisation provokes an analysis of the public education policies implemented both in terms of the right to education and the fight against educational inequalities, since the rapid growth of private schools in the 18 French-speaking countries studied highlights shortcomings of the States in ensuring quality education for all children.

\section{REFERENCES}

André G. \& Poncelet M., 2013, "Héritage colonial et appropriation du 'pouvoir d'éduquer'. Approche socio-historique du champ de l'éducation primaire en RDC", Cahiers de la recherche sur l'éducation et les savoirs, no. 12, pp. 271-295. 
Assane Igodoe A., 2018, "Les enseignantes du primaire au Niger: agents de promotion de la scolarisation des filles?", Cahiers de la recherche sur l'éducation et les savoirs, no. 17, pp. 75-95.

Azoh F.-J., Lanoue É. \& Tchombe T., 2009, Éducation, violences, conflits et perceptives de paix en Afrique subsaharienne, Karthala, Paris.

Bonini N. \& Lange M.-F., 2016, "L'école en Afrique: principales thématiques de recherche depuis 40 ans", in Regards scientifiques sur l'Afrique depuis les Indépendances, Lafay M., Le Guennec-Coppens F. \& Coulibaly E. (eds), Paris, Karthala, Société des africanistes, pp. 397-418.

Brenner L. \& Sanankoua B. (eds), 1991, L'Enseignement islamique au Mali, Bamako, Éditions Jamana.

Central African Republic, MEPSTA (Ministère de l'Enseignement Primaire, Secondaire, Technique et de l'Alphabétisation), DGESP (Direction Générale des Études, des Statistiques et de la Planification), 2017, Annuaire Statistique 2016/2017.

Charlier J.-E., 2004, “Les écoles au Sénégal: de l'enseignement officiel au daara, les modèles et leurs répliques", Cahiers de la recherche sur l'éducation et les savoirs, no. 3, pp. 35-53.

Compaoré F. \& Pilon M., 2017, “L'évolution de l'offre privée dans l'enseignement primaire au Burkina Faso depuis 2000", Dynamiques éducatives au Burkina Faso: bilan et perspectives, Compaoré M., Kobiané J.-F. and Compaoré F. (eds), Ouagadougou, L'Harmattan Burkina, pp. 273-305.

Compaoré M., 2003, "La refondation de l'enseignement catholique au Burkina Faso", Cahiers d'études africaines, no. 169-170, pp. 87-98.

De Grauwe A., 2016, "Educational Planning For the 2030 Agenda", The IIEP letter: news and analysis on educational planning and management, vol. 32, no. 2, pp. 1-3, http://www.iiep.unesco.org/en/educational-planning-2030 -agenda.

Dia H., Hugon C. \& d'Aiglepierre R., 2016, "États réformateurs et éducation arabo-islamique en Afrique. Vers un compromis historique? Introduction thématique", Afrique contemporaine, no. 257, pp. 11-23.

Gandolfi S., 2003, "L'enseignement islamique en Afrique noire", Cahiers d'études africaines, no. 169-170, pp. 261-278.

Grégoire E. \& Lange M.-F., 2018, "La réhabilitation des politiques publiques en Afrique de l'Ouest et du Centre", L'État réhabilité en Afrique. Revisiter les politiques publiques à l'ère néolibérale, Grégoire E., Kobiané J.-F. and Lange M.-F. (eds), Paris, Karthala, pp. 19-45.

Guth S., 1990, "L'école en Afrique noire francophone: une appropriation institutionnelle", Revue française de pédagogie, no. 90, pp. 71-97.

Guth S., 2003, "Les collégiens et la guerre au Congo", Cahiers d'études africaines, no. 169-170, pp. 337-350.

Hugon C., 2016, “(Re) Penser Dieu à l'école au Sénégal. L'adaptation des politiques publiques au défi de l'éducation 'arabo-islamique", $\mathrm{PhD}$ thesis, political science, École doctorale SP2, Sciences Po Bordeaux, Bordeaux.

Kitaev I., 1999, Private education in sub-Saharan Africa: A re-examination of theories and concepts related to its development and finance, Paris, IIPE/ UNESCO. 
Labelle M., 1987, Idéologie de couleur et classes sociales en Haïti, Montreal, CIDIHCA et Les Presses de l'Université de Montréal.

Lacoste P. \& Leignel L., 2016, "L'éducation aux Comores. Un modèle français en phase de lente hybridation", Revue Tiers Monde, 3, no. 226-227, pp. 197-221.

Lange M.-F., 1998, L'école au Togo. Processus de scolarisation et institution de l'école en Afrique. Paris, Karthala.

Lange M.-F., 2001, (ed. scientific), "Des écoles pour le Sud. Stratégies sociales, politiques étatiques et interventions du Nord", Autrepart, no. 17, pp. 3-182.

Lange M.-F., 2003a, "Vers de nouvelles recherches en éducation", Cahiers d'études africaines, no. 169-170, pp. 7-17.

Lange M.-F., 2003b, "École et mondialisation: vers un nouvel ordre scolaire?", Cahiers d'études africaines, no. 169-170, pp. 143-166.

Lange M.-F. \& Diarra S.O., 1999, “École et démocratie. L' 'explosion' scolaire sous la III" République au Mali”, Politique africaine, no. 76, pp. 164-172.

Lange M.-F. \& Henaff N., 2015, "Politiques, acteurs et systèmes éducatifs entre internationalisation et mondialisation", in special issue on "Internationalisation et transformation des systèmes éducatifs au Sud", Revue Tiers Monde, no. 223, pp. 11-27.

Lange M.-F. \& Yaro Y., 2003, “L'évolution de l'offre et de la demande d'éducation depuis 20 ans en Afrique", paper presented at the international conference, Fourth African Population Conference UAPS/UEPA, 8-12 December, Tunis, Tunisia.

Lange M.-F., Zoungrana C.M. \& Yaro Y., 2006, "Éducation, enfants et société de demain. Exemples africains", in Enfants d'aujourd'hui. Diversité des contextes, pluralité des parcours, Paris, AIDELF, Presses Universitaires de France, no. 11, vol. 2, pp. 1053-1067.

Lanoue É., 2002, Les politiques de l'école catholique en Afrique de l'Ouest: le cas de la Côte-d'Ivoire, $\mathrm{PhD}$ thesis, sociology, EHESS, Paris.

Lanoue É., 2003a, “'Le temps des missionnaires n'est plus!' Le devenir postcolonial de l'enseignement catholique en Côte d'Ivoire (1958-2000)", Cahiers d'études africaines, no. 169-170, pp. 99-120.

Lanoue É., 2003b, “L'école à l'épreuve de la guerre. Vers une territorialisation des politiques d'éducation en Côte d'Ivoire", Politique africaine, no. 92, pp. 129-143.

Lanoue É., 2004, "Les écoles catholiques et la construction des 'identités scolaires' en Côte d'Ivoire", Cahiers de la recherche sur l'éducation et les savoirs, vol. 3, pp. 75-91.

Lewandowski S., 2007, "L'État, 'gestionnaire' de l'éducation? Diversification et privatisation de l'offre scolaire au Burkina Faso", in L'enseignement supérieur dans la mondialisation libérale: Une comparaison libérale (Maghreb, Afrique, Canada, France), Tunis, Research Institute on Contemporary Maghreb, pp. 89-103.

Lewandowski S., 2011, "Politiques de lutte contre la pauvreté et inégalités scolaires à Dakar: vers un éclatement des normes éducatives?", Autrepart, vol. 3, no. 59 , pp. 37-56.

Makonda A., 1988, “Une École 'pour le peuple'?”, Politique africaine, no. 31, pp. 39-50. 
Marchand J., 2000, Les écoles communautaires - Mali, Sénégal, Togo, Paris, UNESCO.

MENFP (Ministère de l'Éducation Nationale et de la Formation Professionnelle), 2011, Recensement scolaire 2010-11, Port-au-Prince, MENFP.

Murseli H., 2018, Politiques éducatives en temps de conflit: le cas de la République centrafricaine pendant le gouvernement de transition de 2014 à 2016, PhD in sociology, demography, Paris, Sorbonne Paris Cité.

Murseli H., 2019, "L'Éducation en situation de conflits en République centrafricaine: les Espaces Temporaires d'Apprentissage en question", Cahiers de la recherche sur l'éducation et les savoirs, no. 18, pp. 73-93.

Nicholls D., 1978, "Race, couleur et indépendance en Haïti (1804-1825)", Revue d'Histoire Moderne \& Contemporaine, vol. 25, no. 2, pp. 177-212.

Republic of Niger, MEP/A/PLN/EC (Ministère de l'Enseignement Primaire, de l'Alphabétisation, de la Promotion des Langues Nationales et de l'Éducation Civique), 2016, Statistiques de l'éducation de base et alphabétisation. Annuaire 2015-2016.

Robinson P., 1994, "The National Conference phenomenon in francophone Africa", Comparative Studies in Society and History, vol. 36, no. 3, pp. 575-610.

Sy D., 2012, L'enseignement coranique au Sénégal, doctoral thesis, sociology, Perpignan.

Triplet A.-C., 2015, "Internationalisation et transformation du système éducatif en situation de post-conflit. Le cas de la Côte d'Ivoire", Revue Tiers Monde, no. 223 , pp. 29-48.

UN, Office for the Coordination of Humanitarian Affairs, 2016, "Haiti: Hurricane Matthew - Situation Report No. 11 (15 October)", https://reliefweb.int/ sites/reliefweb.int/files/resources/SITREP\%2011\%20-\%20HAITI\%20\%2815 $\% 200 C T \% 202016 \% 29$.pdf

Wodon Q., 2014, Education in Sub-Saharan Africa: Comparing faith-inspired, private secular, and public schools, Washington, DC@, The World Bank. 